Tersedia online di http://ojs.unik-kediri.ac.id/index.php/jimek

\title{
Pengaruh Promosi ,Saluran Distribusi Dan Kualitas Pelayanan Terhadap Keputusan Pembelian Produk Valve Pt Valmatic Indonesia
}

\author{
Muhammad Agung Anggoro ${ }^{1}$, May Chel ${ }^{2}$ Bambang Purnomo ${ }^{3}$ \\ 1,2,3,) Program Studi Manajemen Fakultas Ekonomi Universitas Prima \\ Indonesia \\ ${ }^{1}$ muhammadagunganggoro@unprimdn.ac.id, ${ }^{2}$ maychelma01@gmail.com, \\ 33ambangpur@gmail.com
}

\section{Artikel History:}

Artikel masuk : 04-03-2020

Artikel revisi : $13-03-2020$

Artikel diterima : 23-06-2020

Keywords:

Promosi, Saluran Ditribusi,

Kualitas Pelayanan dan

Keputusan Pembelian

\section{ABSTRAK}

Penelitian ini diadakan di PT Valmatic Indonesia yang bergerak di bidang distributor produk valve. Penelitian ini dilakukan untuk menguji dan menganalisis pengaruh promosi, saluran distribusi dan kualitas pelayanan terhadap keputusan pembelian produk valve pada PT Valmatic Indonesia. Penelitian ini menggunakan pendekatan kuantitatif, deskriptif kuantitatif dan explanatory. Populasi penelitian ini adalah 161 pelanggan PT. Valmatic Indonesia. Untuk menghitung sampel digunakan rumus Slovin dengan teknik simple random sampling sebanyak 115 responden dan 30 responden diluar dari sampel untuk pengujian validitas dan reliabilitas. Metode analisis data yang digunakan adalah analisis regresi linear berganda. Hasil penelitian menunjukkan baik secara simultan maupun secara parsial promosi, saluran distribusi dan kualitas pelayanan berpengaruh positif dan signifikan terhadap keputusan pembelian produk valve pada PT Valmatic Indonesia. Berdasarkan uji koefisien determinasi dapat diketahui besarnya pengaruh variabel yang diteliti adalah sebesar 37,\% sisanya dipengaruhi oleh variabel lain yang tidak diteliti yaitu sebesar $62,4 \%$.

\section{ABSTRACT}

This research was conducted at PT Valmatic Indonesia which is engaged in the distributor of valve products. This research was conducted to test and analyze the effect of promotion, distribution channels and service quality on the purchase decision of valve products at PT Valmatic Indonesia. This research uses a quantitative, quantitative and explanatory approach. The population of this study was 161 customers of PT. Valmatic Indonesia. To calculate the sample the Slovin formula is used with a simple random sampling technique of 115 respondents and 30 respondents outside the sample for testing the validity and reliability. The data analysis method used is multiple linear regression analysis. The results showed that both simultaneously and partially promotion, distribution channels and service quality 
had a positive and significant effect on purchasing decisions for valve products at PT Valmatic Indonesia. Based on the coefficient of determination test it can be seen the magnitude of the influence of the studied variables is 37, the rest $\%$ is influenced by other variables not examined that is equal to $62.4 \%$.

\section{PENDAHULUAN}

Ketatnya persaingan dalam dunia usaha menuntut setiap perusahaan untuk mengambil langkah-langkah dan strategi yang tepat guna memenangkan persaingan dengan kompetitor demi menjaga eksistensi yang dimiliki perusahaan dan tentunya mempertahankan bahkan meningkatkan keuntungan yang dihasilkan. Tanpa strategi yang tepat perusahaan tidak akan dapat bertahan karena seiring waktu kompetitor akan terus muncul bersamaan dengan permintaan konsumen yang kian meningkat. Hal ini dihadapi oleh setiap perusahaan yang mencari laba.

Kegiatan promosi biasanya diadakan perusahaan untuk menarik minat pembeli dengan menginformasikan produk-produk dan menawarkan berbagai penawaran istimewa. Kegiatan tersebut dapat menarik minat pelanggan pada penawaran yang ditawarkan oleh perusahaan melalui promosi sehingga pelanggan tertarik untuk melakukan keputusan pembelian.

Saluran distribusi adalah media yang digunakan oleh perusahaan untuk menyalurkan produk-produk yang dijual kepada pelanggan. Ketepatan waktu saluran distribusi menjadi hal yang paling harus diperhatikan oleh perusahaan. Dengan saluran distribusi yang baik maka pelanggan merasakan kepuasan dalam menggunakan dan membeli produk di perusahaan.

Pelanggan akan mencoba membandingkan kualitas layanan yang diberikan oleh perusahaan, dan dalam hal ini perusahaan dituntut untuk memberikan kualitas layanan yang mampu memberikan nilai yang lebih, sehingga berbeda dengan kualitas layanan persaing karena kualitas pelayanan menjadi salah satu faktor pertimbangan konsumen sebelum membeli produk. Dengan kualitas layanan yang memuaskan, mendorong pelanggan untuk melakukan pembelian produk yang bersangkutan. Jika suatu perusahaan mampu memberikan pelayanan yang baik, secara langsung atau tidak langsung, citra layanannya akan tersebar luas karena kepuasan yang dirasakan pelanggannya akan disampaikan pelanggan yang satu ke pelanggan lainnya secara berantai, sehingga dapat menarik pelanggan yang lebih banyak.

PT Valmatic Indonesia adalah distributor produk valve dengan merek Valmatic yang memiliki kantor pusat di Malaysia dan memiliki 3 kantor cabang di Indonesia yang 
salah satunya adalah di Medan. Adapun produk valve tersebut dipasarkan pada pelanggan yang bergerak di bidang industri yang penggunaannya untuk transportasi air. Biasanya promosi yang diadakan oleh PT Valmaric Indonesia adalah mengadakan pameran, mengadakan kunjungan langsung ke pelanggan untuk perkenalan dan presentasi produk, memberikan parcel kepada contact person pada saat hari Raya dan membuat website yang dapat memesan dan melihat foto produk yang ingin dipesan. Untuk lebih jelasnya kegiatan promosi yang dilakukan oleh PT Valmaric Indonesia pada tahun 2018 sebagai berikut :

Tabel I.1 Kegiatan Bauran Promosi Tahun 2018

\begin{tabular}{|c|c|c|c|}
\hline Bulan & Jenis Promosi & $\begin{array}{c}\text { Alat } \\
\text { Promosi }\end{array}$ & Masalah \\
\hline Januari & Publisitas & Website & Jarang di update \\
\hline Februari & $\begin{array}{l}\text { Promosi } \\
\text { penjuala }\end{array}$ & Parcel & $\begin{array}{l}\text { Pembagian parcel kepada beberapa contact } \\
\text { person yang memberikan keuntungan kepada }\end{array}$ \\
\hline Maret & Iklan & Brosur & Detail produk kurang spesifik \\
\hline April & $\begin{array}{l}\text { Promosi } \\
\text { penjuala }\end{array}$ & Cash back & $\begin{array}{l}\text { Cash back sebesar 5\% yang hanya berlaku bagi } \\
\text { pembelian tunai }\end{array}$ \\
\hline Mei & $\begin{array}{l}\text { Pemasara } \\
\mathrm{n}\end{array}$ & Email & $\begin{array}{l}\text { Tidak semua pelanggan mereply / menanggapi } \\
\text { email yang dikirim oleh perusahaan }\end{array}$ \\
\hline Juni & Personal selling & Sales & Kemampuan sales dalam menerangkan produk \\
\hline Juli & Publisitas & pameran & Tidak menginformasikan kepada pelanggan untuk \\
\hline Agustus & Pemasaran & marketing & Mengadakan sosialisasi dengan pelanggan \\
\hline September & - & - & - \\
\hline Oktober & Iklan & Koran & dilakukan hanya sekali saja \\
\hline November & Promosi & Bonus penjualan & Sebagian produk yang ingin dipesan pelanggan tidak \\
\hline Desember & Iklan & kalender & Membagikan kalender yang ada gambar produk \\
\hline
\end{tabular}

Sumber : PT Valmaric Indonesia, (2019)

Berdasarkan informasi ini dapat dilihat jika kegiatan promosi yang diadakan oleh perusahaan masih sangat minim. Adapun kegiatan promosi yang paling disukai oleh pelanggan adalah pemberian cash back, namun dalam hal ini perusahaan kurang memperhatikan keinginan pelanggannya dimana pemberian cash back hanya berlaku bagi pembelian tunai saja. Pada bulan September 2018 perusahaan tidak mengadakan kegiatan promosi, hal ini dikarenakan terbatasnya anggaran promosi sehingga pada bulan September perusahaan meniadakan kegiatan promosi dimana anggaran promosi yang ada di prioritaskan untuk pemberian bonus pada bulan November.

Selain promosi, permasalahan lainnya adalah pada saluran distribusi dimana perusahaan memiliki kantor pusat di Malaysia dan produk yang didistribusikan tersebut dibeli dari negara Jerman, Korea, Denmark, Inggris, Amerika, Australia, Jepang dan Perancis. Dalam penjualan produk tersebut perusahaan memiliki item stok standard namun jika jumlah pemesanan produk mencapai minimum kuantiti maka perusahaan akan melakukan order produk. Dari saluran distribusi ini dapat dilihat permasalahan yang sering terjadi adalah lamanya produk sampai ke pelanggan (Medan) sehingga pelanggan sering 
mengeluh karena pemesanan produk sudah dibayarkan DP terlebih dahulu. Untuk lebih jelasnya dapat dilihat data jumlah pelanggan yang setiap bulan terjadi keterlambatan produk diterima oleh pelanggan.

Tabel I.2 Data Jumlah Pelanggan Produk Terlambat Tiba Tahun 2018

\begin{tabular}{|l|c|c|}
\hline \multicolumn{1}{|c|}{ Bulan } & Pelanggan & Total Pelanggan \\
\hline Januari & 2 & 131 \\
\hline Februari & 3 & 125 \\
\hline Maret & 4 & 144 \\
\hline April & 2 & 153 \\
\hline Mei & 6 & 138 \\
\hline Juni & 3 & 154 \\
\hline Juli & 4 & 157 \\
\hline Agustus & 3 & 148 \\
\hline September & 6 & 161 \\
\hline Oktober & 5 & 160 \\
\hline November & 7 & 157 \\
\hline Desember & 4 & 161 \\
\hline
\end{tabular}

Sumber : PT Valmaric Indonesia, 2019

Berdasarkan data di atas dapat diketahui jika setiap bulannya terjadi masalah keterlambatan penerimaan produk yang dipesan oleh pelanggan. Hal ini dikarenakan produk yang dipesan oleh pelanggan tidak semua ready di Medan sehingga harus dipesan langsung dari Malaysia, selain itu produk yang tiba di pelabuhan mengalami kendala adanya dokumen yang harus diperiksa dan memakan waktu untuk diproses bongkar muat. Pada bulan November sebanyak 7 pelanggan yang produk dipesan oleh pelanggan tidak tiba tepat waktu, hal ini dikarenakan transportasi yang dipilih oleh perusahaan untuk mendistribusikan produk Valve dari Malaysia ke kantor cabang Medan Adalah melalui jalur laut menggunakan kapal laut dimana pada bulan November sering terjadi keterlambatan karena gelombang air sangat tinggi.

Selain permasalahan pada promosi dan saluran distribusi, adanya pelayanan dalam proses aktivitas penjualan produk kepada pelanggan kurang sesuai dengan harapan pelanggan yang mana dapat menyebabkan pelanggan kecewa sehingga pelanggan di kemudian hari dapat berpindah ke perusahaan lain. Berikut ini adalah data keluhan pelanggan yang merasa kualitas pelayanan kurang sesuai dengan harapan pelanggan :

Tabel I.3 Data Keluhan Pelanggan Tahun 2018 


\begin{tabular}{|c|c|c|}
\hline Januari & 3 & \multirow{5}{*}{$\begin{array}{l}\text { a. Karyawan lambat dalam memproses } \\
\text { pesanan pelanggan } \\
\text { b. Karyawan lambat dalam mereply } \\
\text { permintaan penawaran pelanggan }\end{array}$} \\
\hline Februari & 2 & \\
\hline Maret & 4 & \\
\hline April & 3 & \\
\hline Mei & 4 & \\
\hline Juni & 4 & c. Karyawan sering melakukan kesalahan \\
\hline Juli & 3 & dalam pencetakan invoice \\
\hline Agustus & 5 & \\
\hline September & 4 & d. Karyawan melakukan \\
\hline Oktober & 6 & \\
\hline November & 5 & e. Karyawan kurang mereply informasi \\
\hline Desember & 8 & kejelasan produk yang belum tiba \\
\hline
\end{tabular}

Sumber : PT Valmaric Indonesia, 2019

Berdasarkan tabel di atas dapat dilihat adanya beberapa keluhan dari pelanggan. Keluhan biasanya disampaikan pelanggan secara langsung kepada sales ataupun kepada supervisor melalui handphone, setelah itu sales atau supervisor akan menindaklanjutkan keluhan pelanggan dengan memberitahukan kepada bagian yang bersangkutan. Hal ini kurang efisien karena perusahaan tidak memiliki bagian yang khusus menangani keluhan pelanggan sehingga sering kali keluhan pelanggan kurang ditanggapi dan terhenti begitu saja. Pada bulan Desember 2018 banyak pelangga mengeluh, dikarenakan pada bulan Desember sebagian karyawan mengambil cuti tahunan sehingga kurangnya jumlah karyawan khususnya pada bagian penjualan dan logistik sehingga kebutuhan pelanggan tidak ditertangani dengan baik.

Dalam kegiatan penjualan produk valve tersebut terdapat banyak pesaing dengan berbagai merek sehingga dapat dilihat angka penjualan yang kurang stabil dari bulan ke bulan pada tahun 2018 yang dapat dilihat pada tabel berikut ini :

Tabel 1.4 Data Penjualan PT Valmatic Indonesia

\begin{tabular}{|l|c|c|r|}
\hline \multicolumn{1}{|c|}{ Bulan } & Target Penjualan & Realisasi Penjualan & Persentase \\
\hline Januari & 1.500 .000 .000 & 1.330 .142 .600 & $88,68 \%$ \\
\hline Februari & 1.500 .000 .000 & 1.247 .951 .000 & $83,20 \%$ \\
\hline Maret & 1.500 .000 .000 & 1.427 .624 .000 & $95,17 \%$ \\
\hline April & 1.500 .000 .000 & 1.400 .671 .000 & $93,38 \%$ \\
\hline Mei & 1.500 .000 .000 & 1.304 .850 .000 & $86,99 \%$ \\
\hline Juni & 1.500 .000 .000 & 1.147 .451 .000 & $76,50 \%$ \\
\hline Juli & 1.500 .000 .000 & 1.274 .654 .000 & $84,98 \%$ \\
\hline Agustus & 1.500 .000 .000 & 1.341 .975 .000 & $89,47 \%$ \\
\hline September & 1.500 .000 .000 & 1.248 .275 .000 & $83,22 \%$ \\
\hline Oktober & 1.500 .000 .000 & 1.307 .457 .000 & $87,16 \%$ \\
\hline November & 1.500 .000 .000 & 1.284 .697 .400 & $85,65 \%$ \\
\hline Desember & 1.500 .000 .000 & 1.190 .004 .700 & $79,33 \%$ \\
\hline
\end{tabular}

Sumber : PT Valmatic Indonesia, 2019

Berdasarkan tabel 1.4 dapat dilihat jika pada tahun 2018 penjualan produk valve tidak dapat mencapai target sedangkan penjualan paling rendah terjadi pada bulan Juni 2018 dikarenakan banyaknya hari libur sehingga kegiatan penjualan pun berkurang. 
Tidak tercapainya target penjualan ini harus diperhatikan oleh perusahaan agar produk perusahaan tidak digeser oleh kompetior dan tidak kehilangan pelanggannya. Namun pada bulan Maret 2018 penjualan mencapai titik tertinggi dikarenakan perusahaan mengadakan sosialisasi inovasi produk baru yang lebih unggul dengan mencetak brosur yang langsung dibagikan kepada pelanggan dan melakukan demo produk.

Berdasarkan permasalahan yang terjadi pada perusahaan, maka peneliti melakukan penelitian pada perusahaan ini dengan judul : "Pengaruh Promosi, Saluran Distribusi dan Kualitas Pelayanan Terhadap Keputusan Pembelian produk Valve PT Valmatic Indonesia."

\section{Identifikasi Masalah}

Dari uraian latar belakang masalah di atas, maka masalah dalam penelitian ini dapat diidentifikasi sebagai berikut :

1. Promosi yang diadakan oleh perusahaan masih sangat minim

2. Saluran distribusi yang mengalami hambatan karena harus diimport dari luar negeri

3. Adanya kualitas pelayanan yang belum memadai karena belum sesuai dengan harapan pelanggannya

4. Keputusan pembelian yang tidak stabil yang dapat dilihat dari tidak tercapainya target penjualan dan penjualan yang naik turun.

\section{TINJAUAN PUSTAKA}

\section{Teori Tentang Promosi}

Menurut Morissan (2010 : 25), "Promosi merupakan elemen atau bagian dari pemasaran yang digunakan perusahaan untuk berkomunikasi dengan konsumennya".

Menurut Hasan (2014:72), indikator-indikator promosi diantaranya adalah :

1. Periklanan

Periklanan : tema, anggaran menurut produk, kampanye, media, frekuensi tayang, dan evaluasi.

2. Pemasaran langsung

Pemasaran langsung : jumlah pengiriman surat, jumlah panggilan telepon.

3. Selling

- Penjualan tatap muka : jumlah dan jenis penjualan, anggaran menurut wilayah, jumlah petugas, kompensasi, kuota, pelatihan dan evaluasi.

- Promosi penjualan : anggaran menurut produk, jenis, frekuensi, evaluasi 


\section{Teori Tentang Saluran Distribusi}

Menurut Tan (2012:200) saluran distribusi adalah sekelompok pedagang dan agen perusahaan yang mengombinasikan pemindahan fisik dan nama dari suatu produk untuk menciptakan kegunaan bagi pasar tertentu.

Menurut Abdullah dan Tantri (2010:213), indikator saluran distribusi adalah:

1. Kesatuan ukuran

2. Waktu penantian

3. Kemudahan menyebar

4. Variasi produk

5. Dukungan pelayanan

\section{Teori Tentang Kualitas Layanan}

Menurut Sangadji dan Sopiah (2013:99), "Kualitas layanan merupakan suatu kondisi dinamis yang berhubungan dengan produk,Jasa,Manusia,Proses dan Lingkungan Yang memenuhi atau melebihi Harapan"

Menurut Sangadji dan Sopiah (2013:100-101), "Dimensi kualitas adalah:

1. Keandalan (reliability)

2. Daya tanggap (responsiveness)

3. Jaminan (assurance)

4. Empati

5. Produk-produk fisik (tangibles)

\section{Teori Tentang Keputusan Pembelian}

Menurut Sudaryono (2016 : 99), "Keputusan sebagai suatu pemilihan tindakan dari dua atau lebih pilihan alternatif. Dengan kata lain, orang yang mengambil keputusan harus mempunyai satu pilihan dari beberapa alternatif yang tersedia."

Menurut Sunyoto (2014 : 283), setiap keputusan membeli mempunyai struktur sebanyak tujuh. Komponen-komponen tersebut adalah:

1. Keputusan tentang bentuk produk

2. Keputusan tentang jenis produk

3. Keputusan tentang merek

4. Keputusan tentang penjualnya

5. Keputusan tentang jumlah produk 
6. Keputusan tentang waktu pembelian

7. Keputusan tentang cara pembayaran

\section{Kerangka Konseptual}

Berdasarkan teori yang telah dijelaskan sebelumnya maka kerangka konseptual yang akan digunakan sebagai berikut :

\section{Gambar I.1}

Kerangka Konseptual

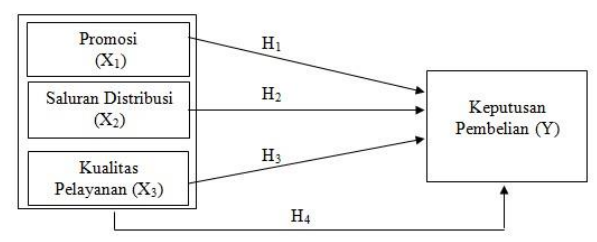

\section{Hipotesis Penelitian}

Menurut Sugiyono (2013 : 64), hipotesis merupakan jawaban sementara terhadap rumusan masalah penelitian, dimana rumusan masalah penelitian telah dinyatakan dalam bentuk kalimat pertanyaan. Dikatakan sementara, karena jawaban yang diberikan baru didasarkan pada teori yang relevan, belum didasarkan pada fakta-fakta empiris yang diperoleh melalui pengumpulan data. Hipotesis dari penelitian ini adalah:

H1 : Promosi secara parsial berpengaruh terhadap keputusan pembelian Valve pada PT. Valmatic Indonesia.

H2 : Saluran distribusi secara parsial berpengaruh terhadap keputusan pembelian Valve pada PT. Valmatic Indonesia.

H3 : Kualitas pelayanan secara parsial berpengaruh terhadap keputusan pembelian Valve pada PT. Valmatic Indonesia.

H4 : Promosi, saluran distribusi dan kualitas pelayanan secara simultan berpengaruh terhadap keputusan pembelian Valve pada PT. Valmatic Indonesia.

\section{METODE PENELITIAN}

\section{LokasidanWaktuPenelitian.}

Penelitian ini dilakukan di PT. Valmatic Indonesia yang beralamat di Jalan Willem Iskandar Kompleks MMTC, Blok C 49, Medan 20371. Penelitian ini dimulai sejak bulan September 2019 sampai April 2020.

\section{Metode Penelitian}




\section{Pendekatan Penelitian}

Menurut Sugiyono (2017 : 8), "Metode penelitian kuantitatif dapat diartikan sebagai metode penelitian yang berlandaskan pada filsafat positivisme, digunakan untuk meneliti pada populasi atau sampel tertentu, pengumpulan data menggunakan instrumen penelitian, analisis data bersifat kuantitatif/statistik, dengan tujuan untuk menguji hipotesis yang telah ditetapkan".

\section{Jenis Penelitian}

Menurut Sanusi (2014:14) untuk penelitian deskriptif-kuantitatif, alat analisis data yang digunakan berupa statistik deskriptif. Peneliti menjelaskan fakta tersebut dengan menggunakan hasil olahan data.

\section{Sifat Penelitian}

Sifat penelitian ini adalah penelitian explanatory. Menurut Zulganef (2013 : 11), "Penelitian explanatory adalah penelitian yang bertujuan menelaah kausalitas antar variabel yang menjelaskan suatu fenomena tertentu".

\section{Populasi dan Sampel}

\section{Populasi}

Populasi dalam penelitian ini adalah rata-rata jumlah pelanggan tetap di PT Valmatic Indonesia tahun 2019 sebanyak 161 pelanggan.

\section{Sampel}

Teknik pengambilan sampel dalam penelitian ini menggunakan simple random sampling. Menurut Sugiyono (2017:120) simple random sampling karena pengambilan anggota sampel dari populasi dilakukan secara acak tanpa memperhatikan strata yang ada dalam populasi itu. Menurut Sanusi (2014 : 101), untuk mengetahui berapa sampel yang akan diambil peneliti menggunakan rumus Slovin yaitu sebagai berikut:

$N$

$$
n=\frac{}{1+N e^{2}}=\frac{}{1+(161)(0,05)^{2}}
$$

161

$$
=114,795=115
$$

\footnotetext{
Keterangan:

$n=$ ukuran sampel

$N=$ jumlah populasi

$e=$ toleransi ketidaktelitian (dalam persen) $5 \%$
} 
Jadi sampel penelitian ini adalah sebanyak 115 responden, dimana 30 responden diambil dari luar sampel untuk pengujian validitas dan reliabilitas.

\section{Teknik Pengumpulan Data}

Teknik pengumpulan data dapat dilakukan dengan beberapa carayaitu:

1. Wawancara (Interview) : dilakukan dengan tanya jawab secara langsung dengan karyawan PT Valmatic Indonesia bagian penjualan untuk memperoleh informasi mengenai promosi, saluran distribusi dan keputusan pembelian.

2. Daftar pertanyaan (Questionare) : membuat angket pertanyaan dan mendistribusikan kuesioner kepada pelanggan PT Valmatic Indonesia. Dalam pengukuran nilai jawaban menggunakan skala likert sebagai skala pengukur.

3. Studi dokumentasi : mengumpulkan teori-teori yang berhubungan dengan promosi, saluran distribusi dan keputusan pembelian.

\section{Jenis dan Sumber Data}

Jenis penelitian ini menggunakan data kuantitatif. Sumber data yang diperlukan dalam penelitian ini adalah :

1. Data Primer.

Data primer dalam penelitian ini bersumber dari penyebaran angket kepada pelanggan PT Valmatic Indonesia melalui.

2. Data Sekunder

Data sekunder dalam penelitian ini berupa data yang berkaitan dengan masalah penelitian, teori-teori buku, jurnal dan literatur yang berhubungan dengan masalah yang diteliti.

\section{Identifikasi dan Definisi Operasional Variabel Penelitian}

Identifikasi dan definisi operasional variabel penelitian ini dapat dilihat pada Tabel

Tabel II.1

Definisi Operasional Variabel

Penelitian

\begin{tabular}{|c|c|c|c|}
\hline Variabel & Definisi Operasional & Indikato & Pengukura \\
\hline $\begin{array}{l}\text { Promosi } \\
\qquad\left(\mathrm{X}_{1}\right)\end{array}$ & $\begin{array}{l}\text { Promosi merupakan } \\
\text { pemasaran yangsi } \\
\text { mengkomunikasikan program-program } \\
\text { pemasaran secara } \\
\text { persuasive kepada target pelanggan } \\
\text { atau calon pelanggan untuk } \\
\text { mendorong terciptanya transaksi- } \\
\text { pertukaran antara perusahaan dan } \\
\text { pelanggan } \\
\text { Sumber : Hasan (2014: } \\
603)\end{array}$ & $\begin{array}{l}\text { 1. Periklanan } \\
\text { 2. Pemasaran langsung } \\
\text { 3. Selling. } \\
\text { Sumber : Hasan }(2014: 72)\end{array}$ & Skala Likert \\
\hline
\end{tabular}




\begin{tabular}{|c|c|c|c|}
\hline $\begin{array}{c}\text { Saluran } \\
\text { Distribus } \\
\text { i }\left(\mathrm{X}_{2}\right)\end{array}$ & $\begin{array}{l}\text { Saluran pemasaran merupakan suatu } \\
\text { sistem jaringan organisasional } \\
\text { pernatara (agen, pedagang dan } \\
\text { retailer) yang } \\
\text { terorganisis untuk melakukan semua } \\
\text { aktivitas pemasaran yang diperlukan } \\
\text { dalam menghubungkan produsen } \\
\text { dengan konsumen datau pengguna } \\
\text { atau pembeli baik barang atau jasa. } \\
\text { Sumber : Hasan } \\
(2013: 577)\end{array}$ & $\begin{array}{l}\text { 1. Kesatuan ukuran } \\
\text { 2. Waktu penantian } \\
\text { 3. Kemudahan menyebar } \\
\text { 4. Variasi produk } \\
\text { 5. Dukungan pelayanan } \\
\text { Sumber : Abdullah dan } \\
\text { Tantri } \\
(2010: 213)\end{array}$ & Skala Likert \\
\hline $\begin{array}{c}\text { Keputusa } \\
\text { n } \\
\text { Pembelia } \\
\text { n (Y) }\end{array}$ & $\begin{array}{l}\text { Keputusan pembelian adalah } \\
\text { semua perilaku sengaja } \\
\text { dilandaskan pada keinginan yang } \\
\text { dihasilkan ketika konsumen secara } \\
\text { sadar memilih salah satu diantara } \\
\text { tindakan alternatif yang ada Sumber: } \\
\text { Sangadji dan Sopiah (2013:121) }\end{array}$ & $\begin{array}{l}\text { 1. Keputusan tentang jenis produk. } \\
\text { 2. Keputusan tentang bentuk produk } \\
\text { 3. Keputusan tentang merek } \\
\text { 4. Keputusan tentang penjualan } \\
\text { 5. Keputusan tentang jumlah produk } \\
\text { 6. Keputusan tentang waktu } \\
\text { pembelian } \\
\text { 7. Keputusan tentang } \\
\text { cara pembayaran. } \\
\text { Sumber: Sudaryono (2016:119) }\end{array}$ & Skala Likert \\
\hline
\end{tabular}

\section{Uji Validitas dan Reliabilitas Instrumen Variabel}

\section{Uji Validitas}

Menurut Torang (2016:289-291), uji validitas dimaksudkan untuk mengukur valid atau tidaknya suatu kuesioner. Untuk mengukur tingkat validitas dapat dilakukan dengan cara membandingkan nilai rhitung dengan nilai rtabel untuk degree of freedom = $n-k=30-2=28$, dalam alpha 0,05 didapat rtabel 0,361.

\section{Uji Reliabilitas}

MenurutPriyatno (2013 : 30), "Suatu alat pengukur dikatakan reliabel bila alat itu dalam mengukur suatu gejala pada waktu yang berlainan senantiasa menunjukkan hasil yang sama. Jadi alat yang reliabel secara konsisten member hasil ukuran yang sama”.

\section{Uji Asumsi Klasik}

Uji asumsi klasik digunakan untuk mengetahui ada tidaknya normalitas residual, multikolinearitas, autokorelasi dan heteroskedastisitas pada model regresi. Model regresi linear dapat disebut sebagai model yang baik jika model tersebut memenuhi beberapa asumsi klasik, yaitu data residual terdistribusi normal, tidak adanya multikolinearitas, autokorelasi dan heteroskedastisitas. Harus terpenuhinya asumsi klasik karena agar diperoleh model regresi dengan estimasi yang tidak bias dan 
pengujian dapat dipercaya. Apabila ada satu syarat saja yang tidak terpenuhi, hasil analisis regresi tidak dapat dikatakan bersifat BLUE (Best Linear Unbiased Estimator).

\section{Model Analisis Data Penelitian}

\section{Model Penelitian}

Rumus persamaan analisis regresi linear berganda sebagai berikut :

$$
\mathbf{Y}=\mathbf{a}+\mathbf{b}_{1} \mathbf{X}_{1}+\mathbf{b}_{2} \mathbf{X}_{2}+\mathbf{e}
$$

$$
\begin{aligned}
& \text { Keterangan : } Y=\text { Keputusan pembelian (dependent variabel) } \\
& X_{1}=\text { Promosi (independent variabel) } \\
& X_{2}=\text { Saluran Distribusi (independent variabel) } \\
& a \quad=\text { Konstanta } \\
& b_{1}, b_{2} \quad=\text { Koefisien untuk variabel bebas } \\
& e \quad=\text { Persentase kesalahan }(5 \%)
\end{aligned}
$$

\section{Koefisien Determinasi $\left(R^{2}\right)$}

Menurut Ghozali (2013:97),"Koefisien determinasi $\left(R^{2}\right)$ pada intinya mengukur seberapa jauh kemampuan model dalam menerangkan variasi variabel dependen". Nilai koefisien determinasi adalah antar nol sampai satu $\left(0<\mathrm{R}^{2}<1\right)$.

\section{PengujianHipotesis Secara Simultan (UjiF)}

Menurut Ghozali (2013:98), "Uji statistik $F$ pada dasarnya menunjukkan apakah semua variabel bebas yang dimasukkan dalam model mempunyai pengaruh secara simultan terhadap variabel dependen". Dalam penelitian ini nilai Fhitung akan dibandingkan dengan nilai Ftabel, pada tingkat signifikan $(\alpha)=5 \%$.

\section{Pengujian Hipotesis Secara Parsial (Ujit)}

Menurut Ghozali (2013:98), "Ujit digunakan untuk melihat secara parsial apakah ada pengaruh yang signifikan dari variabel bebas terhadap variabel terikat. Dalam penelitian ini nilai $t$ hitung akan dibandingkan dengan nilai $t$ tabel, pada tingkat signifikan $(\alpha)=5 \%$.

\section{HASIL \& PEMBAHASAN}

\section{Hasil Penelitian}

\section{Statistik Deskriptif}


Responden pada penelitian ini berjumlah 115 pelanggan PT. Valmatic Indonesia. Berikut ini adalah statistik deskriptif dari jawaban minimum, maksimum dan ratarata para responden, yaitu:

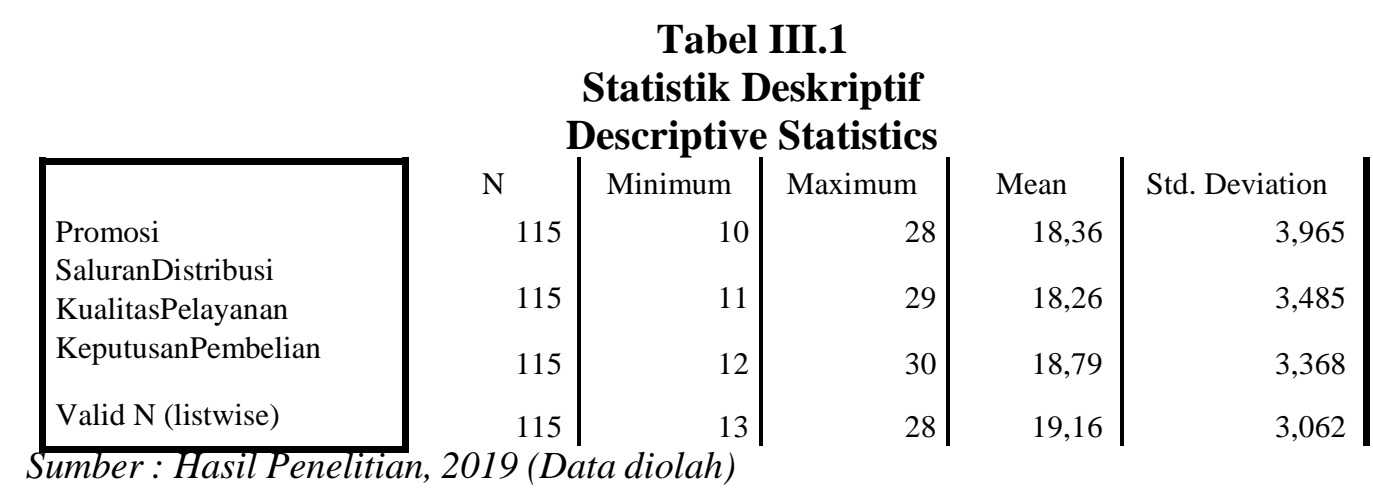

Hasil total jawaban terendah variabel promosi adalah 10 yaitu jawaban dari responden nomor 106. Hasil total jawaban tertinggi variabel promosi adalah 28 yaitu jawaban dari responden nomor 68. Rata-rata jawaban responden atas pertanyaan promosi yaitu 18,36 .

Hasil total jawaban terendah variabel saluran distribusi adalah 11 yaitu jawaban dari responden nomor 99. Hasil total jawaban tertinggi variabel saluran distribusi adalah 29 yaitu jawaban dari responden nomor 26. Rata-rata jawaban responden atas pertanyaan saluran distribusi yaitu 18,26.

Hasil total jawaban terendah variabel kualitas pelayanan adalah 12 yaitu jawaban dari responden nomor 43 dan 60 . Hasil total jawaban tertinggi variabel kualitas pelayanan adalah 30 yaitu jawaban dari responden nomor 27. Rata-rata jawaban responden atas pertanyaan kualitas pelayanan yaitu 18,79 .

Hasil total jawaban terendah variabel keputusan pembelian adalah 13 yaitu jawaban dari responden nomor 56. Hasil total jawaban tertinggi variabel keputusan pembelianadalah 28 yaitu jawaban dari responden nomor 9 dan 35. Rata-rata jawaban responden atas pertanyaan keputusan pembelian yaitu 19,16.

\section{Hasil Uji Asumsi Klasik}

\section{Uji Normalitas}

Uji normalitas bertujuan untuk menguji apakah dalam model regresi, variabel pengganggu atau residual memiliki distribusi normal. Kalau uji normalitas ini dilanggar maka uji statistik menjadi tidak valid untuk jumlah sampel yang kecil. 


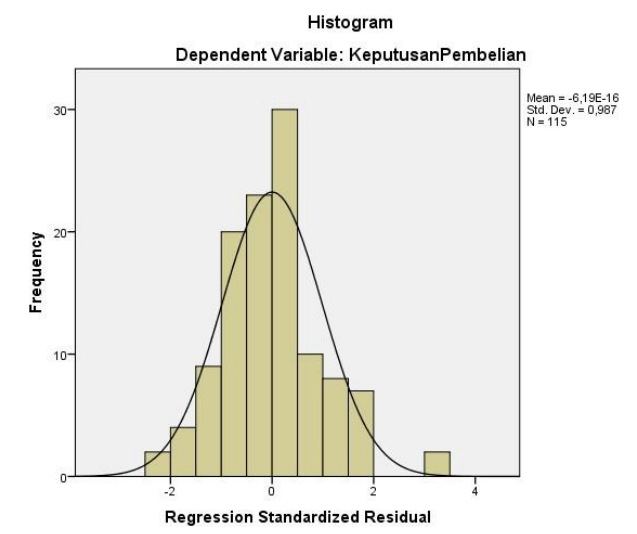

Gambar III.1

Uji Normalitas Histogram

Sumber : Hasil Penelitian, 2019 (Data diolah

Grafik histogram pada Gambar III.1 menunjukkan data riil membentuk garis kurva cenderung simetri (U) tidak melenceng ke kiri atau pun ke kanan maka dapat dikatakan data berdistribusi normal.

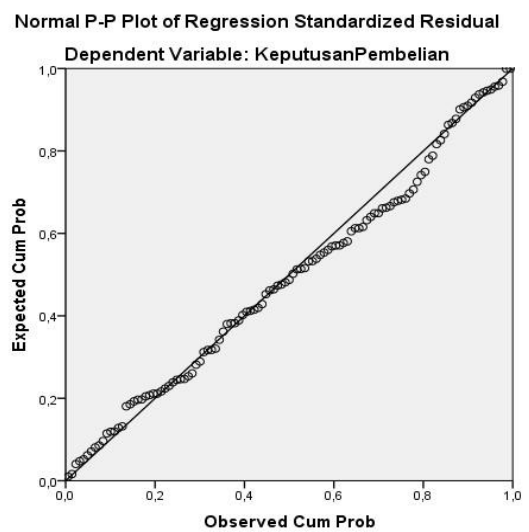

Gambar III.2

Uji Normalitas P-P Plot

Sumber : Hasil Penelitian, 2019 (Data diolah)

Grafik Normalitas pada Gambar III.2 diatas, terlihat titik-titik menyebar disekitar garis diagonal, penyebarannya sebagian besar mendekati garis diagonal. Uji normalitas secara statistik perlu dilakukanuntuk memastikan apakah data benar-benar telah terdistribusi normal.Berikut ini adalah uji normalitas secara statistik menggunakan Kolmogorov Smirnov. Kriteria pengujiannya adalah sebagai berikut:

a. Jika nilai signifikansi $>0,05$, maka data berdistribusi normal

b. Jika nilai signifikansi $<0,05$, maka data tidak berdistribusi normal

Tabel III.2 
Uji Normalitas Kolmogorov Smirnov

One-Sample Kolmogorov-Smirnov Test

\begin{tabular}{|c|c|c|}
\hline \multirow{2}{*}{\multicolumn{2}{|c|}{$\mathrm{N}$}} & Unstandardized Residual \\
\hline & & 115 \\
\hline \multirow{3}{*}{ Normal Parameters ${ }^{\mathrm{a}, \mathrm{b}}$} & Mean &, 0000000 \\
\hline & Std. Deviation & 2,38695018 \\
\hline & Absolute &, 078 \\
\hline Most Extreme Differences & Positive & ,078 \\
\hline
\end{tabular}

a. Test distribution is Normal.

b. Calculated from data.

Sumber : Hasil Penelitian, 2019 (Data diolah)

Hasil uji normalitas Kolmogorov Smirnov menunjukkan nilai signifikan 0,478>0,05 dengan demikian dari hasil uji Kolmogorov Smirnovmenunjukkan data berdistribusi normal.

\section{Uji Multikolinearitas}

Uji multikolinearitas bertujuan untuk menguji apakah pada model regresi ditemukan adanya korelasi antar variabel independen. Pada model regresi yang baik seharusnya tidak terjadi korelasi antar variabel independen. Pengujian multikolinearitas dilakukan dengan melihat VIF antar variabel independen.

\section{Tabel III.3}

Uji Multikolinearitas Coefficients $^{\mathrm{a}}$

\begin{tabular}{|c|c|c|c|}
\hline \multicolumn{4}{|c|}{ Coefficients $^{\mathbf{a}}$} \\
\hline Model & & Collinearity & tistics \\
\hline & & Tolerance & VIF \\
\hline & Promosi & ,514 & 1,947 \\
\hline & - SaluranDistribusi &, 860 & 1,162 \\
\hline & 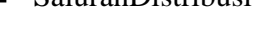 & ,512 & 1,954 \\
\hline
\end{tabular}

a. Dependent Variable: KeputusanPembelian

Sumber : Hasil Penelitian, 2019 (Data diolah)

Dengan demikian pada uji Multikolinearitas tidak terjadi korelasi antar variabel independen promosi, saluran distribusi dan kualitas pelayanan karena nilai tolerance > 0,10 dan nilai $\mathrm{VIF}<10$.

\section{Uji Heteroskedastisitas}

Suatu model regresi yang baik adalah tidak terjadi heteroskedastisitas. Ada beberapa cara untuk menguji ada tidaknya situasi heteroskedastisitas dalam varian error terms untuk model regresi. Menurut Ghozali (2011:139), "Deteksi ada tidaknya heterokedastisitas dapat dilakukan dengan melihat ada tidaknya pola tertentu pada grafik scatterplot antara SRESID 
dan ZPRED dimana sumbu $\mathrm{Y}^{\prime}$ adalah $\mathrm{Y}$ yang diprediksi, dan sumbu $\mathrm{X}$ adalah residual (Y prediksi - Y sesungguhnya) yang telah di studentized."

Dalam penelitian ini akan digunakan metode chart (Diagram Scatterplot), dengan dasar pemikiran bahwa :

1. Jika ada pola tertentu seperti titik-titik (poin-poin), yang ada membentuk suatu pola tertentu yang beraturan (bergelombang, melebar, kemudian menyempit), maka terjadi heteroskedastisitas.

2. Jika ada pola yang jelas, serta titik-titik menyebar keatas dan dibawah 0 pada sumbu Y maka tidak terjadi heteroskedastisitas.

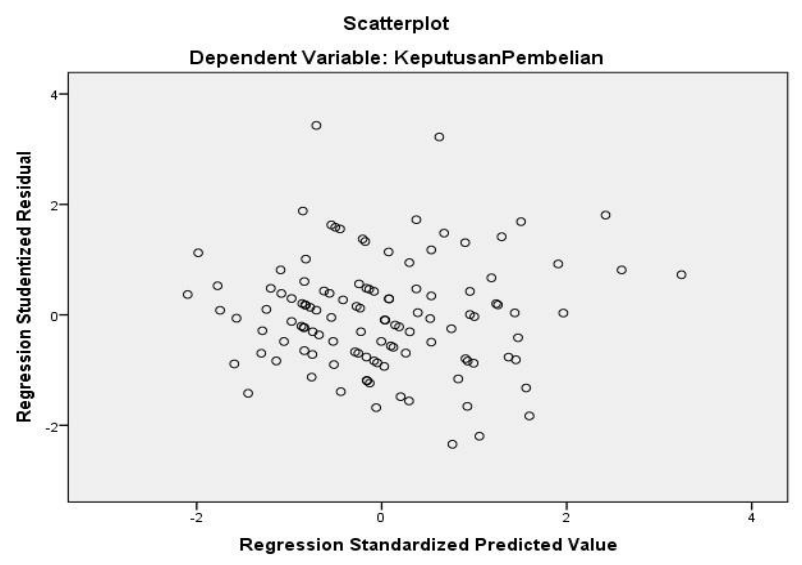

Gambar III.3

Uji Heteroskedastisitas Scatterplot

Sumber : Hasil Penelitian, 2019 (Data diolah)

Dari grafik scatterplot terlihat bahwa titik-titik menyebar dengan pola yang tidak jelas baik diatas maupun dibawah angka nol (0) pada sumbu Y, tidak berkumpul disatu tempat, sehingga dari grafik scatterplotdapat disimpulkan bahwa tidak terjadi heteroskedastisitas pada model regresi.

Pendeteksian ada tidaknya heteroskedastisitas bisa juga dilakukan dengan menggunakan metode Glejser Test.Uji glejser ini dilakukan dengan meregresikan variabelvariabel bebas terhadap nilai absolute residual. Sebagai pengertian dasar, residual adalah selisih antara nilai observasi dengan nilai prediksi, dan absolut adalah nilai mutlaknya. Jika nilai signifikasi antara variabel independen dengan residual lebih dari 0,05 maka tidak terjadi heterokedastisitas. 
3. Koefisien regresi saluran distribusi sebesar 0,212 dan bernilai positif, hal ini menyatakan bahwa setiap kenaikan saluran distribusi sebesar 1 satuan akan mengakibatkan kenaikan keputusan pembelian sebesar 0,212 satuan.

4. Koefisien regresi kualitas pelayanan sebesar 0,250 dan bernilai positif, hal ini menyatakan bahwa setiap kenaikan kualitas pelayanan sebesar 1 satuan akan mengakibatkan kenaikan keputusan pembelian sebesar 0,250 satuan.

\section{Koefisien Determinasi Hipotesis $\left(\mathbf{R}^{2}\right)$}

Koefisien determinasi ditujukan untuk mengetahui seberapa besar kemampuan model dalam menerangkan variabel terikat. Jika koefisien determinasi $\left(\mathrm{R}^{2}\right)$ semakin besar atau mendekati 1, maka dapat dikatakan bahwa kemampuan variabel bebas $(\mathrm{X})$ adalah besar terhadap variabel terikat $(\mathrm{Y})$.

\section{Tabel III.6}

\section{Uji Koefisien Determinasi}

\begin{tabular}{|c|c|c|c|c|}
\hline & \multicolumn{4}{|c|}{ Model Summary } \\
\hline Model & $\mathrm{R}$ & R Square & Adjusted R & Std. Error of the \\
\hline 1 &, $627^{\mathrm{a}}$ & ,393 & ,376 & 2,419 \\
\hline
\end{tabular}

a. Predictors: (Constant), KualitasPelayanan, SaluranDistribusi, Promosi

Sumber : Hasil Penelitian, 2019 (Data diolah)

Hasil Uji Koefisien Determinasi diperoleh nilai Adjusted $R$ square sebesar 0,376 hal ini berarti $37,6 \%$ dari variasi variabel dependen keputusan pembelian dapat dijelaskan oleh variabel independen promosi, saluran distribusi dan kualitas pelayanan sedangkan sisanya sebesar 62,4\% (100\% - 37,6\%) dijelaskan oleh variabel lain yang tidak digunakan pada penelitian ini.

\section{Pengujian Hipotesis Secara Simultan (Uji F)}

Uji F digunakan untuk menunjukkan apakah semua variabel independen promosi, saluran distribusi dan kualitas pelayanan yang dimasukkan dalam model mempunyai pengaruh secara bersama-sama terhadap variabel dependen keputusan pembelian. Hasil Uji hipotesis secara simultan adalah sebagai berikut :

\section{Tabel III.7}

Uji F

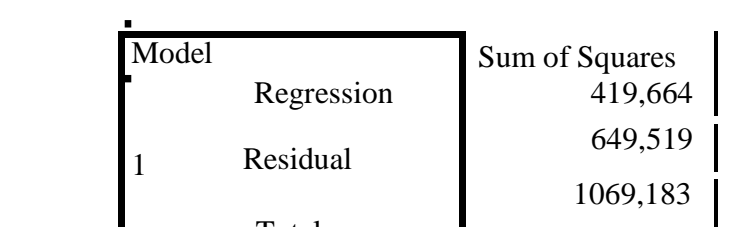

ANOVA $^{\mathrm{a}}$

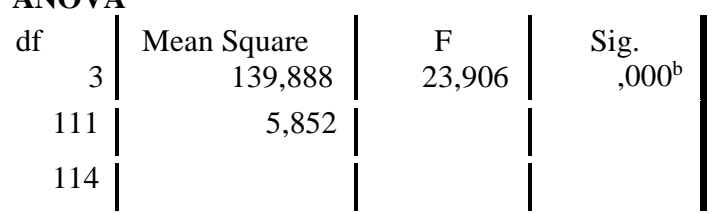


a. Dependent Variable: KeputusanPembelian

b. Predictors: (Constant), KualitasPelayanan, SaluranDistribusi, Promosi

Sumber : Hasil Penelitian, 2019 (Data diolah)

Pada derajat bebas $1\left(\mathrm{df}_{1}\right)=3$, dan derajat bebas $2\left(\mathrm{df}_{2}\right)=111$, maka besarnya nilai $\mathrm{F}$ tabel pada taraf kepercayaan signifikansi 0,05 adalah 2,69.

Dari hasil perhitungan SPSS diperoleh nilai $\mathrm{F}$ hitung $=23,906>\mathrm{F}$ tabel $=2,69$ dengan tingkat signifikansi 0,000 karena $\mathrm{F}$ hitung $=23,906>\mathrm{F}$ tabel $=2,69$ dan probabilitas signifikansi 0,000 < 0,05, Maka $\mathrm{Ha}$ diterima artinya promosi, saluran distribusi dan kualitas pelayanan secara simultan berpengaruh positif signifikan terhadap keputusan pembelian produk Valve pada PT. Valmatic Indonesia.

\section{Pengujian Hipotesis Secara Parsial (Uji t)}

Pengujian t-test digunakan untuk menunjukkan seberapa jauh pengaruh satu variabel independen terhadap variabel dependen

\section{Tabel III.8}

\section{Uji t}

Coefficients $^{\mathbf{a}}$

\begin{tabular}{|c|c|c|c|c|c|}
\hline \multirow[b]{2}{*}{ Model, } & \multicolumn{3}{|c|}{ Coefficients } & \multirow{3}{*}{$\mathrm{t}$} & \multirow{3}{*}{ Sig. } \\
\hline & Unstandardize & oefficients & Standardized & & \\
\hline & B & Std. Error & Beta & & \\
\hline " $($ Constant $)$ & 6,850 & 1,518 & & 4,512 & 000 \\
\hline - Promosi & ,204 & ,080 & 264 & 2,562 & 012 \\
\hline SaluranDistribusi & ,212 & ,070 & ,241 & 3,022 & ,003 \\
\hline KualitasPelayanan & ,250 & ,094 & ,274 & 2,654 & ,009 \\
\hline
\end{tabular}

a. Dependent Variable: KeputusanPembelian

Sumber : Hasil Penelitian, 2019 (Data diolah)

Nilai t tabel untuk probabilitas 0,05 pada derajat bebas $n-k=111$ adalah sebesar 1,98157. Dengan demikian hasil dari Uji t dapat dijelaskan sebagai berikut:

1. Pada variabel promosi diperoleh nilai $\mathrm{t}$ hitung $>\mathrm{t}$ tabel atau 2,562 >1,98157 dan signifikan $0,012<0,05$ maka $\mathrm{Ha}$ diterima artinya secara parsial promosi berpengaruh positif dan signifikan terhadap keputusan pembelian produk Valve pada PT. Valmatic Indonesia.

2. Pada variabel saluran distribusi diperoleh nilai t hitung $>\mathrm{t}$ tabel atau 3,022 > 1,98157 dan signifikan $0,003<0,05$ maka $\mathrm{Ha}_{\mathrm{a}}$ diterima artinya secara parsial saluran distribusi berpengaruh positif dan signifikan terhadap keputusan pembelian produk Valve pada PT. Valmatic Indonesia.

3. Pada variabel kualitas pelayanan diperoleh nilai t hitung $>t$ tabel atau 2,654 > 
1,98157 dan signifikan $0,009<0,05$ maka $\mathrm{Ha}_{\mathrm{a}}$ diterima artinya secara parsial kualitas pelayanan berpengaruh positif dan signifikan terhadap keputusan pembelian produk Valve pada PT. Valmatic Indonesia.

\section{Pembahasan Hasil Penelitian}

\section{Pengaruh Promosi Terhadap Keputusan Pembelian}

Hasil analisis menunjukkan bahwa promosi berpengaruh positif dan signifikan terhadap keputusan pembelian produk Valve pada PT. Valmatic Indonesia dengan nilai t hitung $>\mathrm{t}$ tabel atau 2,562 > 1,98157 dan nilai signifikan 0,012<0,05.

Hasil penelitian ini sama dengan hasil penelitian Fernando dan Aksari (2018) yaitu promosi berpengaruh positif dan signifikan terhadap keputusan pembelian produk.

Hasil penelitian ini juga sependapat dengan Herlambang (2014:56), dengan promosi menyebabkan orang yang sebelumnya tidak tertarik untuk membeli suatu produk akan menjadi tertarik dan mencoba produk sehingga konsumen melakukan pembelian.

\section{Pengaruh Saluran distribusi Terhadap Keputusan Pembelian}

Hasil analisis menunjukkan bahwa saluran distribusi berpengaruh positif dan signifikan terhadap keputusan pembelian produk Valve pada PT. Valmatic Indonesia dengan nilai $\mathrm{t}$ hitung $>\mathrm{t}$ tabel atau 3,022 > 1,98157 dan nilai signifikan sebesar 0,003 < 0,05 .

Hasil penelitian ini sama dengan hasil penelitian Irawan dan Satrio (2015) yaitu saluran distribusi berpengaruh positif dan signifikan terhadap keputusan pembelian.

Hasil penelitian ini juga sependapat dengan Varian, dkk (2019:130) Ketepatan waktu saluran distribusi menjadi hal yang paling harus diperhatikan oleh perusahaan. Dengan saluran distribusi yang baik maka pelanggan akan nyaman dalam menggunakan dan membeli produk di perusahaan.

\section{Pengaruh Kualitas pelayanan Terhadap Keputusan Pembelian}

Hasil analisis menunjukkan bahwa kualitas pelayanan berpengaruh positif dan signifikan terhadap keputusan pembelian produk Valve pada PT. Valmatic Indonesia dengan nilai t hitung $>\mathrm{t}$ tabel atau 2,654 > 1,98157 dan nilai signifikan sebesar 0,009 $<0,05$.

Hasil penelitian ini sama dengan hasil penelitian Amrullah, dkk (2016) yaitu kualitas pelayanan berpengaruh positif dan signifikan terhadap keputusan pembelian.

Hasil penelitian ini juga sependapat dengan Suchaeri (2012 : 5-6), pelanggan akan merasakan kepuasan dan kesenangan karena kualitas layanan yang diberikan. Mereka akan kembali untuk berkunjung dan membeli. Pelayanan yang luar biasa tidak 
diciptakan hanya dalam waktu sekejap. Semua dihasilkan dari proses perbaikan sebelumnya. Keluhan pelanggan merupakan sekolah terbaik untuk peningkatan kinerja sebuah perusahaan.

\section{SIMPULAN \& SARAN}

\section{Kesimpulan}

Kesimpulan dari hasil penelitian ini adalah:

1. Secara parsial promosi berpengaruh positif dan signifikan terhadap keputusan pembelian produk Valve pada PT. Valmatic Indonesia dengan nilai t hitung $(2,562)$ $>$ t tabel $(1,98157)$ dan nilai signifikan $0,012<0,05$.

2. Secara parsial saluran distribusi berpengaruh positif dan signifikan terhadap keputusan pembelian produk Valve pada PT. Valmatic Indonesia dengan nilai t hitung $(3,022)>$ t tabel $(1,98157)$ dan nilai signifikan sebesar $0,003<0,05$.

3. Secara parsial kualitas pelayanan berpengaruh positif dan signifikan terhadap keputusan pembelian produk Valve pada PT. Valmatic Indonesiadengan nilai t hitung $(2,654)>\mathrm{t}$ tabel $(1,98157)$ dan nilai signifikan sebesar $0,009<0,05$.

4. Secara simultan promosi, saluran distribusi dan kualitas pelayanan berpengaruh signifikan terhadap keputusan pembelian produk Valve pada PT. Valmatic Indonesia nilai $\mathrm{F}$ hitung $=23,906>\mathrm{F}$ tabel $=2,69$ dengan tingkat signifikansi $0,000<0,05$ dan hasil uji koefisien determinasi menunjukkan $37,6 \%$ dari variasi variabel dependen keputusan pembelian yang dapat dijelaskan oleh variabel independen promosi, saluran distribusi dan kualitas pelayanan sedangkan sisanya sebesar $62,4 \%$ dijelaskan oleh variabel lain yang tidak digunakan pada penelitian ini.

\section{Saran}

Saran-saran yang berguna bagi penelitian selanjutnya adalah:

1. Bagi peneliti selanjutnya

Disarankan untuk menambah variabel lain di luar dari variabel yang diteliti oleh peneliti. Karena hasil uji koefisien menunjukkan sebesar $62,4 \%$ dari variasi variabel keputusan pembelian dipengaruhi oleh variabel lain misalnya kualitas produk, harga, merek dan lain-lain. 
2. Bagi PT. Valmatic Indonesia

Disarankan untuk meningkatkan pengadaan promosi misalnya mengikuti eventevent atau sering mengadakan komunikasi tentang produk dengan pelanggan, meminimalisir keterlambatan saluran distribusi produk dengan memberikan ketepatan waktu pengurusan ekspedisi barang, serta meningkatkan pelayanan terhadap pelanggan dengan selalu tanggap setiap keluhan pelanggan dimana dalam hal ini karyawan perlu diberikan pelatihan agar lebih menguasai bidang pekerjaannya.

3. Bagi Fakultas Ekonomi Universitas Prima Indonesia

Disarankan hasil penelitian diharapkan dapat menambah literatur dalam kepustakaan.

\section{DAFTAR PUSTAKA}

Abdullah, Thamrin dan Francis Tantri. 2014. Manajemen Pemasaran. Ed. 1, Jakarta: PT Grafindo Persada.

Ghozali, Imam. 2013. Aplikasi Analisis Multivariate Dengan Program SPSS.

Semarang: Badan Penerbit Universitas Diponegoro.

Hasan, A. 2014. Marketing Dan Kasus-kasus Pilihan. Jakarta: PT Buku Seru. Morrisan. 2010. Periklanan Komunikasi Pemasaran Terpadu, Cetakan Kesatu.

Jakarta: Kencana.

Sangadji, Etta Mamang dan Sopiah. 2013. Perilaku Konsumen Pendekatan

Praktis. Yogyakarta: CV Andi Offset.

Sanusi, Anwar. 2014. Metodologi Penelitian Bisnis : Disertai Contoh Proposal Penelitian Bidang Ilmu Ekonomi Dan Manajemen. Jakarta: Salemba Empat.

Sudaryono. 2016. Manajemen Pemasaran Teori \& Implementasi. Yogyakarta: CV. Andi Offset.

Sugiyono. 2017. Metode Penelitian Kuantitatif Kualitatif Dan R\&D. Bandung : PT Alfabeta.

Sunyoto, Danang. 2014. Dasar-Dasar Manajemen Pemasaran (Konsep, Strategi, dan Kasus).

Cetakan ke-1. Yogyakarta: CAPS (Center for Academic Publishing Service).

Torang, Syamsir. 2016. Organisasi \& Manajemen (Perilaku, Struktur, Budaya

\& Perubahan Organisasi). Bandung: CV. Alfabet 